\title{
Morphological characterization of the gonads of bullfrog tadpoles (Lithobates catesbeianus)
}

\author{
RIZZI, G. M. ${ }^{1,2 *}$, SILVA-ZACARIN, E. C. M. ${ }^{1}$, OLIVEIRA, C. R. ${ }^{1}$, \\ COSTA, M. J. ${ }^{1}$, SALLA, R. F. ${ }^{1}$ and ABDALLA, F. C. ${ }^{1,2}$ \\ ${ }^{1}$ Laboratório de Biologia Estrutural e Funcional - LABEF, Universidade Federal de São Carlos - UFSCar, \\ Campus Sorocaba, Rodovia João Leme dos Santos, Km 110, CEP 18052-780, Sorocaba, SP, Brasil \\ ${ }^{2}$ Universidade Estadual "Júlio de Mesquita Filho" - UNESP, Campus de Rio Claro, Avenida 24a a 1515, \\ CEP 13506-900, Rio Claro, SP, Brasil \\ *E-mail: gisele.m.rizzi@gmail.com
}

\begin{abstract}
Introduction: This work describes various aspects of early gonadal development of female and male in pre-metamorphic tadpoles (Lithobates catesbeianus) at Gosner stage 25. Materials and Methods: Ovaries and testicles were prepared for routine light microscopy for morphological study and for acridine orange technique fluroescent microscopy for observation of RNA cytoplasm activity. Results: The results showed that female gonads at Gosner stage 25 predominated primary and secondary oogonias, as well as primary, secondary and tertiary oocytes. The developing testicle presented primary spermatogonia (I or A) and secondary spermatogonia (II or B), and as well as primary and secondary spermatocyte. All this cell phases were morphologically characterized and the cell sizes measured. In pre-metamorphic testes the somniferous duct are not developed and the vasa deferentia is opened. Conclusion: At this point, it was possible differentiate ovary from testes does not for the gonadal cells, but for the general anatomy of the organs, being the ovary a spheroid structure and the testicle an elongated tubule.
\end{abstract}

Keywords: amphibians, development, ovary, testicle.

\section{Introduction}

Gametogenesis is the most important process for reproduction (ZUG, VITT and CALDWELL, 2001), and, in adults, it is divided into several stages or phases, according to the cytoplasmic and nuclear changes (PRADO, ABDALLA, SILVA et al., 2004). In adult amphibians, gametogenesis follows a similar pattern to that of other vertebrates, however the number of stages described for each animal varies considerably, depending mainly of the criterion used by the authors and the peculiarity of the species (ABDALLA and CRUZ-LANDIM, 2003).

Lithobates catesbeianus bullfrog (Shaw, 1802) is an anuran naturally distributed in eastern North America, Nova Scotia and the State of Florida (FROST, 2013). Previously described as Rana catesbeiana, was incorporated gender Lithobates in 1943 (FROST, GRANT, FAIVOVICH et al., 2006), although most of the literature about them refer to old taxonomic name.

This semi aquatic species can be found in a wide variety of habitats, but preferably occupies permanent water with thick aquatic vegetation that provides convenient places to escape predators, growth and reproduction. The species presents an accentuated sexual dimorphism, males being smaller than females (KLEMENS, 1993; MOYLE, 1973).

According to Schwalbe and Rosen (1988), bullfrog is an extremely prolific species, with each female producing about 20.000 eggs per spawning and the number of offspring generated by a couple spins around 5.000 per breeding season (HOWARD, 1978). The bi-colored eggs measure approximately $1 \mathrm{~mm}$ in diameter and the roe is laid close to edges of the surface of water, attached to the semi-aquatic vegetation. They hatch in a period between 3 and 5 days.
The newly hatched tadpoles measure about $1 \mathrm{~cm}$ in length (ALTIG and MCDIARMID, 1999).

The early lifecycle of the tadpoles is divided in three phases: embryonic, larval, and metamorphic. After metamorphosis arises the adult or post-embryonic phase. The embryonic stage is the period of fertilization and development within the egg. The larval phase begins with the hatching of the egg and includes the whole period of development of tadpoles. In the third and final phase, the metamorphic, the tadpole changes into an adult frog (ALTIG and MCDIARMID, 1999). Gosner (1960), considering the morphological changes that occur in these phases, subdivided them into 46 stages of development, with the embryonic stage corresponding to stages 1-15; laval corresponding to stages 16-25; the metamorphic phase, corresponding to body growth and early development of the posterior members, stages 26-35. At stages 36-41 the stabilization of body growth and development of the posterior members takes place, and at stages 42-46 the completion of metamorphosis occurs, with externalization of anterior members, resorption of the tail and modification of the jaw.

The tadpoles of this species at Gosner stage 25 measure approximately $8 \mathrm{~cm}$. Despite the vast literature about the morphology of the gonads of adult amphibian anures, the morphology the pre-metamorfic gonadal development of these animals is poorly studied. Therefore, the aim of this study is to perform a morphological description of the gonads of tadpoles of bullfrogs at 25 Gosner, and to characterize the different initial stages of ovarian and testicular maturation. 


\section{Material and Methods}

Tadpoles were obtained from a breeding colony at Ranaville (Santa Bárbara do Oeste, São Paulo State, Southeast Brazil), packed in plastic bags with $80 \mathrm{~L}$ capacity containing water and immediately transported to the Laboratory of Conservation Physiology at Federal University of São Carlos, in Sorocaba. Tadpoles were housed in $50 \mathrm{~L}$ aquaria equipped with a continuous supply $(1.2 \mathrm{~L} / \mathrm{h})$ of well-aerated and dechlorinated water at a constant temperature $\left(25 \pm 1{ }^{\circ} \mathrm{C}\right)$ under natural photoperiod $(\sim 12 \mathrm{~h}$ light/dark cycle) until they reached Gosner (1960) developmental stage 25. After this period, each tadpole was euthanatized by cephalic concussion following the rules of euthanasia of the American Veterinary Medical Association (AMERICAN..., 2001), and had their gonads removed and fixed with the appropriate substance for each type of procedure to be performed: modified Karnovisky (2.5\% glutaraldehyde, sodium cacodylate buffer, $0.1 \mathrm{M}, \mathrm{pH} .7$ 2) for routine light microscopy, and buffered paraformaldehyde (4\% paraformaldehyde in phosphate buffer $0.1 \mathrm{M}, \mathrm{pH} .7 .4$ ) for histochemical technique.

All experiments with the animals were approved by the Institutional Animal Experimentation Committee of the Federal University of São Carlos (protocol 034/2012), in accordance with the Brazilian legislation for Animal Experimentation (COMITÊ..., 2013).

\subsection{Microscopy for high resolution}

After the gonads fixation in Karnovsky, the material was post-fixed in solution of osmium tetroxide $1.67 \%$, in the dark, for $\mathrm{lh}$ and then washed three times in cacodylate buffer for 30 min each. After this, the material was dehydrated (SILVAZACARIN, CHAUZAT, ZEGGANE et al., 2012) in a series of increasing concentrations of ethanol $(15 \%, 30 \%, 50 \%, 70 \%$, $80 \%, 90 \%, 95 \%$ for 40 min each; $100 \%$ ethanol for $1 \mathrm{~h}$; alcohol + xylol for 40 min.; and pure xylol for $\mathrm{l} \mathrm{h}$ ) at a temperature of $4{ }^{\circ} \mathrm{C}$. Then, the material was placed in liquid historesin Epon $\left(\right.$ Leica $\left.^{\circledR}\right)$ plus activator $(1 \mathrm{~mL}: 0.5 \mathrm{mg})$, at $10^{\circ} \mathrm{C}$ for $24 \mathrm{~h}$. After, the material was embedded in historesin (embedding historesin plus catalyst, Hardener, $15 \mathrm{~mL}: 5 \mathrm{~mL}$ ). The material included with the resin was taken at the Leica ${ }^{\circledR}$ (RM 2255) microtome to be sectioned at $1.5 \mu \mathrm{m}$ thickness.

For morphological analysis, slides of gonads were stained with hematoxylin and eosin (HE), sealed with Ervmount and later observed, analyzed and photodocumented with the Leica ${ }^{\circledR}$ (DMl000) photomicroscopy.

\subsection{Fluorescence histochemical technique - Acridine Orange}

The slides were first washed and dried ( 1 day). Once dried, the slides were embedded with polylysine and allowed to dry ( 1 day). Then, the paraffin material was sectioned $(10 \mu \mathrm{m})$ and sequentially placed on the slides that were stored at $4{ }^{\circ} \mathrm{C}$ until used. The slides were placed in a cuvette to be deparaffinized - using a sequential application of xylol for $20 \mathrm{~min}$.; xylol + alcohol (1:1) for $5 \mathrm{~min}$.; $100 \%$ alcohol for $10 \mathrm{~min}$. Then, the rehydration of the slides was performed - with a sequential application of decreasing concentration of alcohol $(95 \%, 70 \%$ e $50 \%, 5 \mathrm{~min}$. each). The slides were washed three times with distilled water and placed in a cuvette containing $250 \mathrm{~mL}$ of distilled water and $125 \mu \mathrm{L}$ of Triton for $10 \mathrm{~min}$.
Then, the slides were washed three times with distilled water again and placed in a cuvette containing citrate buffer (pH. 2.5) at $75^{\circ} \mathrm{C}$ for $5 \mathrm{~min}$. After this time, the slides were placed in a cloud chamber, stained with acridine orange (AO) and covered with a plastic cover slip, for $25 \mathrm{~min}$. Then, the slides were washed three times with distilled water (three baths, 1 min. each). Finally, histological slides were dehydrated - by the application of increasing concentration of acetone $50 \%$, $70 \%$ and pure acetone), for $1 \mathrm{~min}$. each and were sealed with Ervmount. They were stored at $4{ }^{\circ} \mathrm{C}$, in the dark and later observed, analyzed and photodocumented with the Leica ${ }^{\circledast}$ (DM4000) photomicroscopy.

\section{Results}

The gonads of tadpoles at Gosner stage 25 are located in the abdominal cavity and constitute whitish filaments, very fragile and intimately associated with the dorsal wall of the kidneys. They are about $2 \mathrm{~mm}$ wide and $2 \mathrm{~cm}$ at its greatest length.

\subsection{Ovary primordial morphology}

The morphological data for the primordial tadpoles ovaries in the pre-metamorphic stage or Gosner stage 25 indicated sack-like ovaries, with the beginning of the formation of the central cavity of the ovary (also known as ring structure) and oviducts, showing a well-defined external theca with follicular cells lining the entire ovary, which is located between the inner and outer epithelial ovarian.

The primary oogonia are closely associated with the somatic cell wall, delimiting the female gonad or external theca. They are constitutes of smaller cells, not surrounded by pre-follicular cells, with decondensed nuclei chromatin and weakly acidophilic cytoplasm. Such cells have a rounded morphology, approximately $18 \mu \mathrm{m}$ of nuclear diameter and lobular germinal vesicle, containing one or two nucleoli, with location eccentric to the cytoplasm (Figure 1). Secondary oogonias measure approximately $14 \mu \mathrm{m}$ of nuclear diameter and are the second smallest cell of the oogonia lineage. Their cytoplasm is scarce and hyaline, without defined shape (Figure 1). Primary oocytes in the pre-metamorphic tadpole stage measure approximately $38 \mu \mathrm{m}$ of nuclear diameter

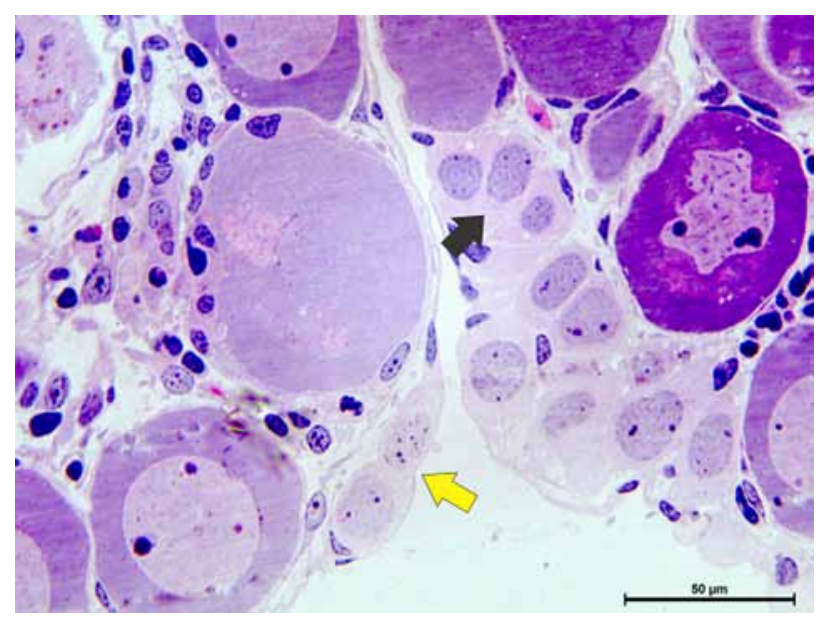

Figure 1. Primordial ovaries of tadpoles in the pre-metamorphic stage or Gosner stage 25 indicated primary oogonia (yellow arrow) and secondary oogonia (black arrow). 
and are larger, being about 3 times larger than oogonia B. They show acidophilic cytoplasm due to the limited amount of RNA present in this phase (Figure 2A and B). This can also be observed by fluorescence staining (Figure 3). Additionally the oocyte development concerning their size and RNA quantity is not synchronic in the ovaries (Figure 3). Their nucleus is large, light stained and have a well-defined shape, with multiple micronucleoli distributed mainly near of the internal face of the nuclear envelope. Inside the oocytes, it can be observed a region described in the literature as an aggregate of RNA and mitochondria, the Balbiani body or nuage. At this stage, these regions are clearly evidenced by yellow in fluorescence and transparent aggregates (cloud-like or, in French, nuage) in routine microscopy scattered throughout the cytoplasm that, in this phase, is predominantly green colored (Figure 3).

Secondary oocytes measure approximately $41 \mu \mathrm{m}$ of nuclear diameter and are larger than the primary oocytes (Figure 2C). Oocytes III presented nuclear diameter measuring approximately $47 \mu \mathrm{m}$, they have centralized and large nucleus. The deposition of cortical granules is a fundamental feature of this type of oocyte (Figure 2D).

\subsection{Morphology of primordial testicle}

The morphological data for the primordial testicle of tadpoles in the pre-metamorphic stage, or Gosner stage 25, indicated that the testicle present lobular form, well-developed tunica albuginea, abundance of somatic cells, proliferation of germ cells, presence of primary spermatogonia (or A), and secondary spermatogonia (or B), primary and secondary spermatocytes. The collecting ducts are long and massive structures still undergoing differentiation. Inside the testicle, the first cysts are forming (Figure 4). In the testicles, the germ cells development is cortical.

Primary spermatogonia (I or A) measure approximately $36 \mu \mathrm{m}$ of nuclear diameter, and are constituted of large cells, with nucleus with very decondensed chromatin and micronucleoli throughout its length (Figure 5A). Whereas, secondary spermatogonia (II or B) measure approximately $25 \mu \mathrm{m}$ of nuclear diameter. They are small and have nucleus with more condensed chromatin (Figure 5B).

Primary spermatocytes that measure approximately $19 \mu \mathrm{m}$ of diameter. These cells are smaller than the spermatogonia $\mathrm{B}$ and have spherical nucleus (Figure 5C). While, secondary spermatocytes measure approximately $15 \mu \mathrm{m}$ of diameter and have nucleus with condensed chromatin (Figure 5D).

\section{Discussion}

As described by Franchi (1962), Lofts (1974) and Ohtani, Miura and Ichikawa (2000), the ovaries of amphibians have sack-like or lobular shape with a cavity inside and a germinal epithelium which gives the ability to a cyclical gonadal proliferation and differentiation of large quantities of gametes. Our results are compatible with those observations.

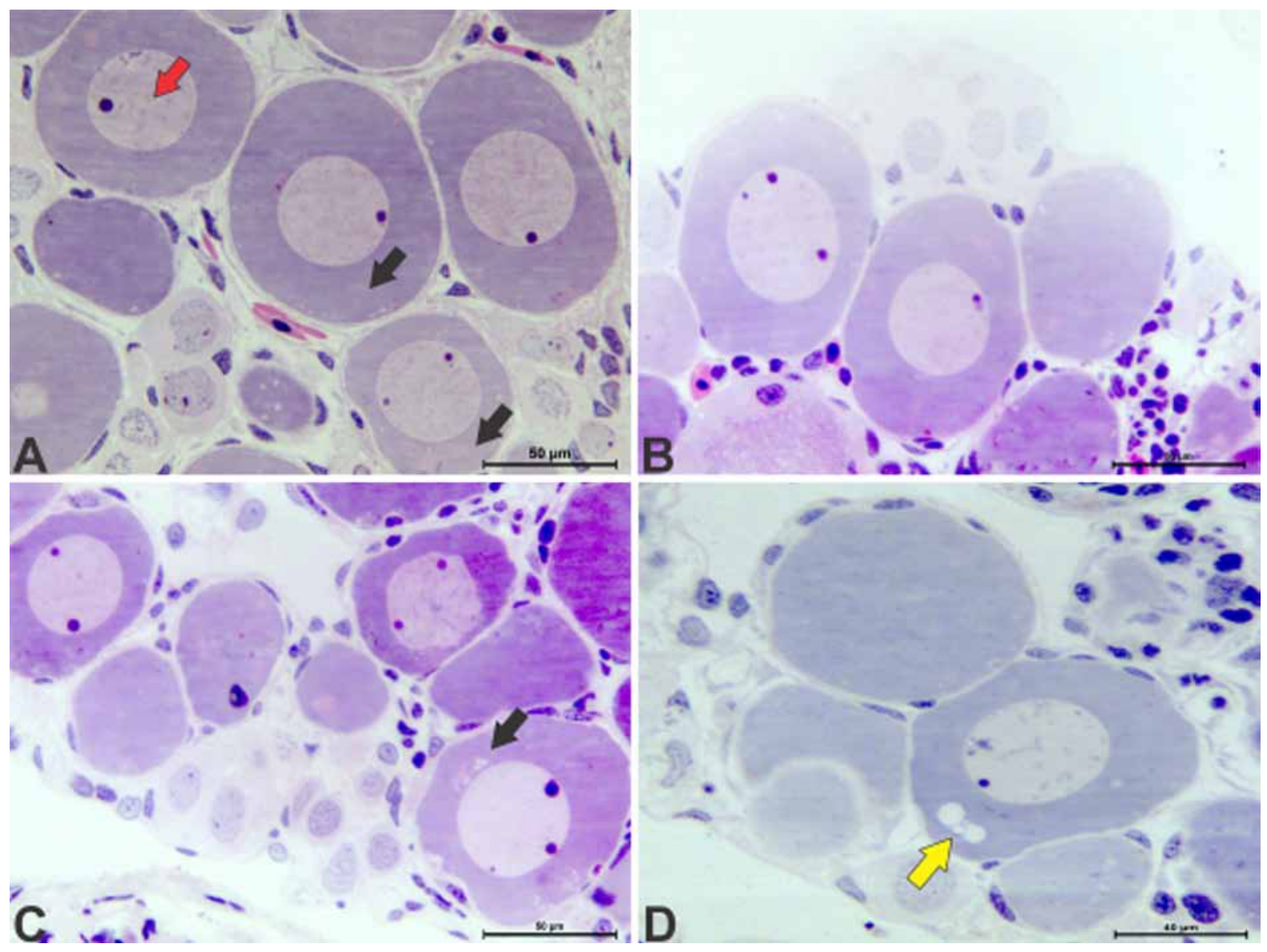

Figure 2. Primordial ovaries of tadpoles in the pre-metamorphic stage or Gosner stage 25. (A and B) Primary oocytes indicated lumpbrush chromosomes (red arrow) and Balbiani body (black arrow); (C) Secondary oocytes with Balbiani body (black arrow); (D) Third oocytes with cortical granules. 


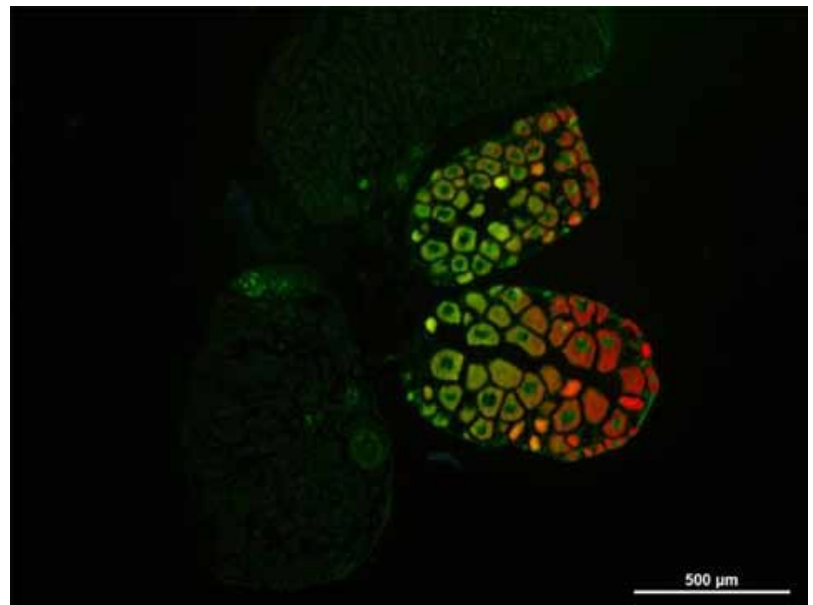

Figure 3. Fluorescence histochemical technique - Acridine Orange - showing the difference in the activity of RNA synthesis in oocytes at different stages. The Balbiani body in this stage are clearly evidenced by yellow coloring.

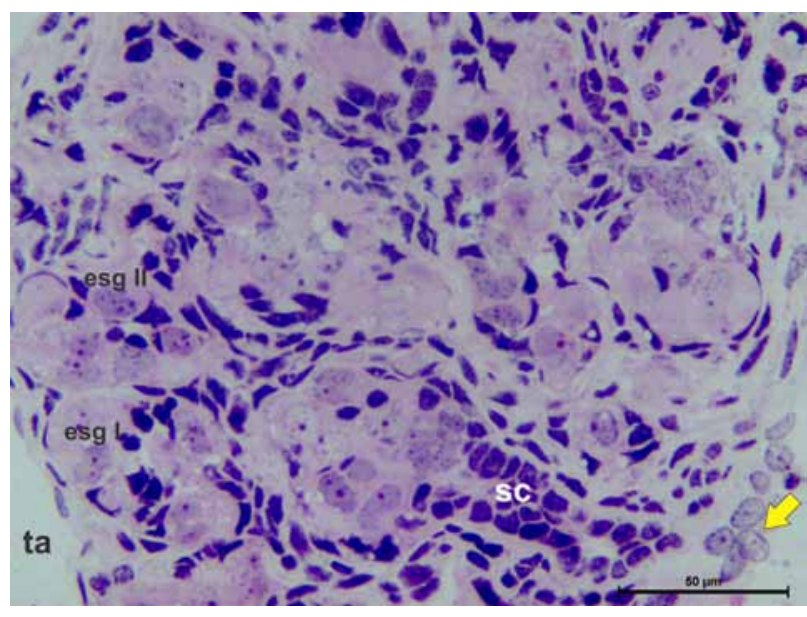

Figure 4. Primordial testicle of tadpoles in the pre-metamorphic stage or Gosner stage 25. (ta) tunica albuginea; (esg I) primary spermatogonia; (esg II) secondary spermatogonia; (sc) somatic cells in the process of differentiation to form the first cysts; yellow arrow clusters of secondary oogonias.

The theca is completely surrounded by the stratum of follicular cells, and is composed principally of collagen, blood vessels and fibroblasts. Occasionally, nerve and smooth muscle cells are observed (DUMONT and BRUMMETT, 1978). In the ovary cavity, somatic or follicular cells lining the entire ovarian in which developing germ cells are observed (HAYES, STUART, MENDOZA et al., 2006). Follicular cells involve all primary ovarian and penetrate inside it, involving groups of oogonia in division. These cells eventually will compose the granular stratum of the developing oocytes (COSTA, LIMA, ANDRADE et al., 1998). The association of oocytes and follicular cells keep the growth and viability of oocytes, as these cells metabolize certain molecules that are transported to the oocytes (SENBON, HIRAO and MIYANO, 2003). Structural and functional changes that occur in these cells during the course of gametogenesis seem to be important to allow the oocyte maturation (SCHUETZ, 1974).
The structure and morphology of oogenesis in tadpoles in pre-metamorphic stage follows the pattern described for fish and other adult amphibians (ABDALLA and CRUZ-LANDIM, 2003, 2004; PRADO, ABDALLA, SILVA et al., 2004), in the ovaries, germ cell development is medullary. The ovaries present in its interior different stages of germ cells, which are classified according to their morphological characteristics: primary oogonia or A, secondary oogonia or B, oocytes I, II and III (AL-MUKHTAR and WEBB, 1971; OLIVEIRA and ANDRADE, 1997).

In the studied tadpoles, the primary ovary is in gonia, i.e., stage of the proliferation of oogonias, giving rise (by successive mitoses) to secondary oogonias, small cells, with nucleus with eccentric position to ooplasma, that present less compact chromatin, measuring less than $10 \mu \mathrm{m}$ of nuclear diameter. They are characterized by a large spherical and weakly basophilic nucleus, as described by Marques, Rosa and Gurgel (2000) and Abdalla, Martins, Silva-Zacarin et al. (2013) for adult amphibians. After the gonia (mitotic division of oogonias A), each secondary oogonia or B will produce only one oocyte, which is evolved by the follicle cells.

Inside the oocytes, a region described in the literature as an aggregate of RNA and mitochondria, the Balbiani body or nuage is in accordance with the description by Costa, Lima, Andrade et al. (1998), Abdalla and Cruz-Landim (2004), Prado, Abdalla, Silva et al. (2004); Okuthe (2012) for adults of anuran. This RNA is condensed in micronucleoli into the nuclei and transferred to the cytoplasm during the early stages of oogenesis (ABDALLA and CRUZ-LANDIM, 2004).

The Balbiani body or muage is commonly referred to, in amphibians, as mitochondrial cloud (GURAYA, 1979; KLOC and ETKIN, 1998; OKUTHE, 2012), it is a complex of cytoplasmic organelles, including the mitochondria, Golgi complex, smooth endoplasmic reticulum e multivesicular bodies. These aggregations differ in their composition and size according to the species (GURAYA, 1979). Balbiani body is not limited to fish and amphibian oocytes (ZELAZOWSKA, KILARSKI, BILINSKI et al., 2007), being also described in many mammalian oocytes in adult (KRESS, 1996). According to Clérot (1979), the association of RNA with mitochondria may have an important role in the replication of these organelles. Its function is not well understood and still requires more studies (OKUTHE, 2012).

The primary oocytes enter meiosis. On the first meiotic division come the first polar body (ABDALLA and CRUZLANDIM, 2003; PRADO, ABDALLA, SILVA et al., 2004). Secondary oocytes present abundant, more granular and less basophilic cytoplasm as described by Costa, Lima, Andrade et al. (1998) for adult amphibians. There is a progressive increase in the number of nucleoli that vary in size and, as the oocyte as develops, it migrate from the central to the nuclear periphery until released into the cytoplasm through nuclear pores (OLIVEIRA and ANDRADE, 1997). The secondary body originates of the secondary oocyte, in the second meiotic division. It will not give rise to functional gametic cells, as well as other polar bodies. From this stage, in the oocytes, the first cortical corpuscles (pre-vitellogenic oocyte) appear. They will accumulate yolk inside and will grow in size (vitellogenic and mature oocytes in adults). In premetaphorfic anuran, the development does not reach the vitellogenic phase (ABDALLA and CRUZLANDIM, 2003; PRADO, ABDALLA, SILVA et al., 2004). 


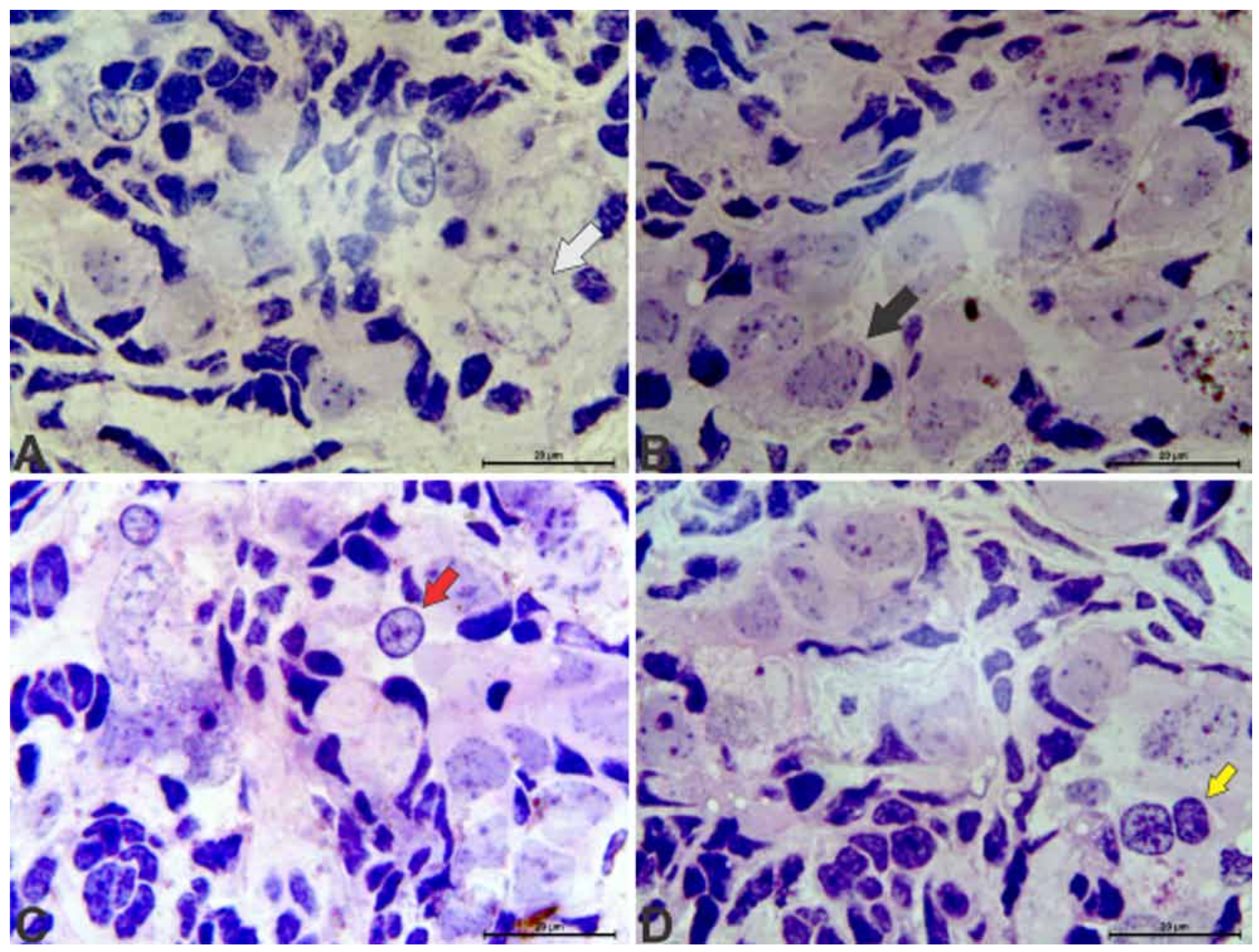

Figure 5. Primordial testicle of tadpoles in the pre-metamorphic stage or Gosner stage 25. (A) Primary spermatogonia (white arrow); (B) Secondary spermatogonia (black arrow); (C) Primary spermatocyte (red arrow); (D) Secondary spermatocyte (yellow arrow).

As described by Oliveira and Andrade (1997), for adult amphibians, oocytes III have centralized nucleus and they are proportionately large. The present work supports those findings. This oocyte marks the beginning of the yolk process (COSTA, LIMA, ANDRADE et al., 1998). The deposition of cortical granules is a fundamental feature of this type of oocyte. These granules are organelles derived from Golgi complex, composed of a wide variety of proteins, structural molecules, enzymes and glycosaminoglycans (FERREIRA, VIREQUE, ADONA et al., 2009). As meiotic maturation progresses, the granules migrate in direction of the oocyte peripheral. At the end of the maturation period, when the oocytes reach meiosis II, the cortical granules are close to the inner surface of the plasma membrane, forming a strategic monolayer to wait for the sperm penetration (THIBAULT, SZÖLLÖSI and GÉRARD, 1987). With fertilization and in response to elevation of intra-oocyte concentration of calcium, granules fuse with the plasma membrane and release their contents into the perivitellinic space (CARNEIRO, LIU, HYDE et al., 2002). This event, known as cortical reaction, is one of the mechanisms to prevent polyspermy. Polyspermy results in unnatural cleavage of the zygote and embryo degeneration (FERREIRA, VIREQUE, ADONA et al., 2009). A fundamental feature of this type of oocyte is RNA predominantly on the cytoplasm, which begins in primary oocytes and reaches its maximum in the third oocyte.

During oogenesis, oocytes stop their development in prophase of meiosis I (diplotene), appearing in their nucleus, regions of DNA, of homologous chromosomes, decondensed and presenting great activity of RNA synthesis. These regions are observable by light microscopy and designated lumpbrush chromosomes. These chromosomes appear in prophase of meiosis of oocytes from different animals. Ultrastructural studies by Rocha and Rocha (2011) during this period suggest a transfer of large amounts of ribosomal RNA from the nucleus to the cytoplasm, since this mechanism is one of several strategies for increasing gene expression. Thus, this method represents a considerable amplification of genes that are transcribed into RNA and on the cytoplasm translated into proteins, which have critical role in early oogenesis.

Differently from ovaries, the tadpole testicle consists of two massive tubular symmetric structures, which presents early developing seminiferous tubules, with germ cells in different stages of development. These cells occur in clusters, within cysts formed by Sertoli cells (COSTA, LIMA, ANDRADE et al., 1998). Our findings are consistent with the study by Costa, Lima, Andrade et al. (1998). Among the species of amphibians, testicle may present cysts in the same developmental stage (synchronous) or at different developmental stages (asynchronous) and, in 
a same cyst, all cells are at the same stage of development. On the final stages of adults, the spermatogenic process goes on and cysts rupture releasing cells (spermatids and sperm) into the lumen of the developed seminiferous tubules (COSTA, LIMA, ANDRADE et al., 1998).

Similarly to the case of ovaries, spermatogenesis of amphibians follows a similar pattern as described for fish (ABDALLA and CRUZ-LANDIM, 2003, 2004; PRADO, ABDALLA, SILVA et al., 2004), but differently of oogenesis, on spermatogenesis meiosis is not interrupted. Testicles are externally covered by a thin layer of connective tissue, where fibroblasts (or somatic cells) are noticeable. In adults, fibroblasts will form the capsule or tunica albuginea, as described by Cruz-Landim, Abdalla and Cruz-Höfling (2004) and Santos and Oliveira (2007).

The primary spermatogonia (I or A) are closely associated with the wall of somatic cells delimiting the male gonad. Secondary spermatogonia (II or B) arise as a result of mitotic division of the primordial germ cells and are further apart from the cells that surround the testicle. After successive mitotic divisions, the $\mathrm{B}$ spermatogonia grow and give rise to primary spermatocytes. Primary spermatocytes enter the meiosis process, finally resulting in the formation of gametes. The prophase of the first meiotic division is a long process, divided into five phases with specific morphological and functional characteristics, called pre-leptotene, leptotene, zygotene, pachytene and diplotene. The primary spermatocyte stage from pre-leptotene to leptotene phase, DNA synthesis and replication occur, causing an increase in cell volume, which culminates in the homogeneous distribution of chromatin at the nucleus (RUSSELL, ETTLIN, SINHA-HIKIM et al., 1990; SEGATELLI, BATLOUNI and FRANÇA et al., 2009). Then, in the primary spermatocytes at zygotene, there is chromosomal thickening, the pairing of homologous chromosomes begins and the synaptonemal complex is formed; the latter being only visible under transmission electron microscopy (BILLARD, 1984, 1986; GRIER and NEYDIG, 2000). This complex persists until the end of the pachytene stage, which is the longest phase of meiotic prophase, in which genetic recombination and segregation occurs, important fact for the diversity of individuals of the same species, presenting completely matched and compact chromosomes. After progressing to the next stage (diplotene), primary spermatocytes complete the first meiotic division giving rise to secondary spermatocytes. They are haploid and pass quickly through the second meiotic division, resulting in the formation of spermatids (RUSSELL, ETTLIN, SINHA-HIKIM et al., 1990). After meiosis II, spermiogenesis begins in spermatids, who suffer from varying degrees of nuclear condensation to give the sperm typically formed by acrosome, head, midpiece and tail (CRUZ-LANDIM, ABDALLA and CRUZ-HÖFLING, 2004).

In the present work, it is not possible to observe spermatids and spermatozoid, because the tadpoles studied are still in the early stage of development.

\section{Conclusion}

In pre-metamorphic stage of the bullfrog tadpoles, we were able to discern that the following early stages occur on the ovaries: primary oogonia (18 $\mu \mathrm{m}$ of nuclear diameter); secondary oogonia (14 $\mu \mathrm{m}$ of nuclear diameter); primary oocytes (38 $\mu \mathrm{m}$ of nuclear diameter); secondary oocytes
(41 $\mu \mathrm{m}$ of nuclear diameter) and third oocytes $(47 \mu \mathrm{m}$ of nuclear diameter).

We were able to discern that the following early stages occur on the testicle: primary spermatogonia (I or A) (36 $\mu \mathrm{m}$ of nuclear diameter); secondary spermatogonia (II or B) (25 $\mu \mathrm{m}$ of nuclear diameter); primary spermatocyte (19 $\mu \mathrm{m}$ of nuclear diameter); and secondary spermatocyte (17 $\mu \mathrm{m}$ of nuclear diameter).

In this study it was not possible to observe spermatids, or sperm, because the tadpoles studied are still in the early stage of development.

\section{References}

ABDALLA, FC. and CRUZ-LANDIM, C. Some histological and ultrastructural aspects of oogenesis in Piaractus mesopotamicus Holmberg, 1887 (Teleostei). Brazilian Journal of Morphological Sciences, 2003, vol. 20, p. 11-18.

ABDALLA, FC. and CRUZ-LANDIM, C. Occurence and ultrastructural characterization of "nuage" during oogenesis and early spermatogenesis of Piaractus mesopotamicus Holmberg, 1887 (Teleostei). Brazilian Journal of Morphological Sciences, 2004, vol. 64, n. 3B, p. 555-561. PMid:15619993.

ABDALLA, FC., MARTINS, LPA., SILVA-ZACARIN, ECS., RIZZI, GM., COSTA, MJ., SALLA, RF., KALININ, AL. and MONTEIRO, DA. The impact of cadmium chloride on the gonadal morphology of the North American bullfrog tadpoles, Lithobates catesbeianus (Shaw, 1802). Fresenius Environmental Bulletin, 2013, vol. 22, n. 7a, p. 1962-1966.

AL-MUKHTAR, KA. and WEBB, AC. An ultrastructural study of primordial germ cells, oogonia and early oocytes in Xenopus laevis. Journal of Embryology and Experimental Morphology, 1971, vol. 26, n. 2, p. 195-217. PMid:5168216.

ALTIG, R. and MCDIARMID, RW. Body plan: developmental and morphology. In ALTIG, R. and MCDIARMID, RW. (Eds.). Tadpoles: the biology of anuran larvae. Chicago: Chicago Press, 1999, p. 24-51.

AMERICAN VETERINARY MEDICAL ASSOCIATION - AVMA. Report of the AVMA Panel on Euthanasia. Journal of the American Veterinary Medical Association, 2001, vol. 218, n. 5, p. 669-696. http://dx.doi.org/10.2460/javma.2001.218.669. PMid:11280396.

BILLARD, R. Ultrastructural changes in the spermatogonia and spermatocytes of Poecilia reticulata during spermatogenesis. Cell and Tissue Research, 1984, vol. 237, n. 2, p. 219-226. http://dx.doi. org/10.1007/BF00217139. PMid:6478490.

BILLARD, R. Spermatogenesis and spermatology of some teleost fish species. Reproduction, Nutrition, Development, 1986, vol. 26, n. 4, p. 877-920. http://dx.doi.org/10.1051/rnd:19860601.

CARNEIRO, G.F., LIU, I.K.M., HYDE, D., ANDERSON, G.B., LORENZO, P.L. and BALL, BA. Quantification and distribution of equine oocyte cortical granules during meiotic maturation and after activation. Molecular Reproduction and Development, 2002, vol. 63, n. 4, p. 451-458. http://dx.doi.org/10.1002/mrd.10198. PMid:12412047.

CLÉROT, JC. Les groupements mitochondriaux des cellules germinales des poisons téléostééns Cyprinidés. Experimental Cell Research, 1979, vol. 120, n. 2, p. 237-244. http://dx.doi.org/10.1016/00144827(79)90383-5. PMid:571344.

COMITÊ DE ÉTICA DA UFSCAR. Available from: <http:// www.propq.ufscar.br/comissoes-de-etica/comissao-de-etica-naexperimentacao-animal>. Access in: 21 Oct. 2013.

COSTA, CLS., LIMA, SL., ANDRADE, DR. and AGOSTINHO, CA. Caracterização morfológica dos estádios de desenvolvimento 
do aparelho reprodutor feminino da rã-touro, Rana catesbeiana, no sistema anfigranja de criação intensiva. Revista Brasileira de Zootecnia, 1998, vol. 27 , n. 4, p. 642-650.

CRUZ-LANDIM, C., ABDALLA, FC. and CRUZ-HÖFLING, MA. Morphological study of the spermatogenesis in the teleost Piaractus mesopotamicus. Biocell, 2004, vol. 27, n. 3, p. 319-328. PMid:15002749

DUMONT, JN. and BRUMMETT, AR. Oogenesis in Xenopus laevis (Daudin). V. Relationships between developing oocytes and their investing follicular tissues. Journal of Morphology, 1978, vol. 155, n. 1, p. 73-97. http://dx.doi.org/10.1002/jmor.1051550106. PMid:619165.

FERREIRA, EM., VIREQUE, AA., ADONA, PR., MEIRELLES, FV., FERRIANI, RA. and NAVARRO, PAAS. Cytoplasmic maturation of bovine oocytes: structural and biochemical modifications and acquisition of developmental competence. Theriogenology, 2009, vol. 71, n. 5, p. 836-848. http://dx.doi.org/10.1016/j.theriogenology.2008.10.023. PMid:19121865.

FRANCHI, L. The structure of the ovary vertebrates. In ZUCKERMAN, SS. (Ed.). The ovary. New York: Academic Press, 1962, p. 129-131.

FROST DR. Amphibian species of the world: an online reference. Versão 5.6. New York: American Museum of Natural History, 2013. Available from: <http://research.amnh.org/herpetology/amphib ia/index. html $>$. Access in: 22 Oct. 2013.

FROST, DR., GRANT, T., FAIVOVICH, J., BAIN, RH., HAAS, A., HADDAD, CFB., SÁ, RO., CHANNING, A., WILKINSON, M., DONNELLAN, SC., RAXWORTHY, CJ., CAMPBELL, JA., BLOTTO, BL., MOLER, P., DREWES, RC., NUSSBAUM, RA., LYNCH, JD., GREEN, DM. and WHEELER, WC. The amphibian tree of life. Bulletin of the American Museum of Natural History, 2006, vol. 297, p. 370. http://dx.doi.org/10.1206/00030090(2006)297[0001:TATOL]2.0.CO;2.

GOSNER KL. A simplified table for staging anuran embryos and larvae with notes on identification. Herpetologica, 1960, vol. 16, p. 183-190.

GRIER, HJ. and NEYDIG, C. Gonads and gametes of fishes. In TIERSCH, TR. and MAZIK, PM. (Eds.). Cryopreservation of aquatic species. Baton Rouge: The World Aquaculture Society, 2000. p. 1-12.

GURAYA, SS. Recent advances in the morphology, cytochemistry and function of Balbiani's vitelline body in animal oocytes. International Review of Cytology, 1979, vol. 59, p. 249-321. http://dx.doi. org/10.1016/S0074-7696(08)61664-2. PMid:385545.

HAYES, TB., STUART, AA., MENDOZA, M., COLLINS, A., NORIEGA, N., VONK, A., JOHNSTON, G., LIU, R. and KPODZO, D. Characterization of Atrazine Induced Gonadal Malformations in African Clawed Frogs (Xenopus laevis) and Comparisons with Effects of an Androgen Antagonist (Cyproterone Acetate) and Exogenous Estrogen (17 $\beta$-Estradiol): Support for the Demasculinization/ Feminization Hypothesis. Environmental Health Perspectives, 2006, vol. 114, n. S-1, supplement 1, p. 134-141. http://dx.doi.org/10.1289/ ehp.8067. PMid:16818259.

HOWARD, RD. The evolution of mating strategies in bullfrogs, Rana catesbeiana. Evolution; International Journal of Organic Evolution, 1978, vol. 32, n. 4, p. 850-871. http://dx.doi.org/10.2307/2407499.

KLEMENS MW. Amphibians and reptiles of Connecticut and adjacent regions. Hartford: Connecticut Department of Environmental Protection, 1993. State Geological and Natural History Survey of Connecticut Bulletin, n. 112.

KLOC, M. and ETKIN, L. Apparent continuity between the messenger transport organizer and late RNA localization pathways during oogenesis in Xenopus. Mechanisms of Development, 1998, vol. 73, n. 1, p. 95-106. http://dx.doi.org/10.1016/S0925-4773(98)000410. PMid:9545550.
KRESS, A. A comparison of oocyte organelles in Monodelphis domestica with those of other Marsupials and Eutherians. Reproduction, Fertility, and Development, 1996, vol. 8, n. 4, p. 521-533. http://dx.doi. org/10.1071/RD9960521. PMid:8870077.

LOFTS, B. Reproduction. In LOFTS, B. (Ed.). Physiology of the amphibia. New York: Academic Press, 1974. p. 107-218.

MARQUES, DKS., ROSA, IL. and GURGEL, HCB. Descrição histológica de gônadas de traíra Hoplias malabaricus (Bloch) (Osteichthyes, Erythrinidae) da barragem do rio Gramame, Alhandra, Paraíba, Brasil. Revista Brasileira de Zoologia, 2000, vol. 17, n. 3, p. 573-582. http://dx.doi.org/10.1590/S0101-81752000000300002.

MOYLE, PB. Effects of introduced bullfrogs, Rana catesbeiana, on the native frogs of the San Joaquin Valley, California. Copeia, 1973, vol. 1973, n. 1, p. 18-22. http://dx.doi.org/10.2307/1442351.

OHTANI, H., MIURA, I. and ICHIKAWA, Y. Effects of dibutyl phthalate as an environmental endocrine disruptor on gonadal sex differentiation of genetic males of the frog Rana rugosa. Environmental Health Perspectives, 2000, vol. 108, n. 12, p. 1189-1193. http:// dx.doi.org/10.1289/ehp.001081189. PMid:11133400.

OKUTHE GE. Follicle formation and oocyte growth in the silver butter catfish, Schilbe intermedius Rüppell, 1832 (Siluriformes, Schilbeidae). Indian Journal of Fisheries, 2012, vol. 59, n. 4, p. 11-18.

OLIVEIRA, C. and ANDRADE, UJA. Anatomia dos ovários e corpos adiposos de Scinax fuscovaria (Anura, Hylldae). Acta Biologica Leopoldensia, 1997, vol. 19, n. 2, p. 173-183.

PRADO, CPA., ABDALLA, FC., SILVA, APZ. and ZINA, J. Late gametogenesis in Leptodactylus labyrinthicus (Amphibia, Anura, Leptodactylidae) and some ecological considerations. Brazilian Journal of Morphological Sciences, 2004, vol. 21, p. 177-184.

ROCHA C A.M. and ROCHA, SMM. MYC gene amplification in gastric adenocarcinoma. Academic Journal of Cancer Research, 2011, vol. 4 , n. 1, p. 18-23.

RUSSELL, LD., ETTLIN, RA., SINHA-HIKIM, AP. and CLEGG, ED. Mammalian spermatogenesis. In RUSSELL, LD., ETTLIN, RA., SINHA-HIKIM, A. and CLEGG, ED. (Eds.). Histological and histopathological evaluation of the testis. Clearwater: Cache River Press, 1990. p. 1-40.

SANTOS, L.R. and OLIVEIRA, C. Morfometria testicular durante o ciclo reprodutivo de Dendropsophus minutus(Peters) (Anura, Hylidae). Revista Brasileira de Zoologia, 2007, vol. 24, n. 1, p. 64-70. http:// dx.doi.org/10.1590/S0101-81752007000100008.

SCHUETZ, A.W. Role of hormones in oocyte maturation. Biology of Reproduction, 1974, vol. 10, n. 2, p. 150-178. http://dx.doi. org/10.1095/biolreprod10.2.150. PMid:4462823.

SCHWALBE, CR. and ROSEN, PC. Preliminary report on effect of bullfrogs on wetland herpetofauna in southeastern Arizona. In SZARO, RC., SEVERSON, KE. and PATTON, DR. (Eds.). Proceedings of the Symposium on Management of Amphibians, Reptiles and Small Mammals in North America. Arizona: USDA Forest Service, 1988. p. 166-173. General Technical Report.

SEGATELLI, TM., BATLOUNI, R. and FRANÇA, LR. Duration of spermatogenesis in the bullfrog (Lithobates catesbeianus). Theriogenology, 2009, vol. 72, n. 7, p. 894-901. PMid:19683337.

SENBON, S., HIRAO, Y. and MIYANO, T. Interactions between the oocyte and surrounding somatic cells in follicular development: lessons in vitro culture. The Journal of Reproduction and Development, 2003, vol. 49, n. 4, p. 259-269. http://dx.doi.org/10.1262/jrd.49.259. PMid:14967918.

SILVA-ZACARIN, E.C.M., CHAUZAT, M.P., ZEGGANE, S., DRAJNUDEL, P., SCHURR, F., FAUCON, J.P., MALASPINA, O. and ENGLER, J.A. Protocol for optimization of histological, histochemical and immunohistochemical analyses of larval tissues: 
RIZZI, G. M., SILVA-ZACARIN, E. C. M., OLIVEIRA, C. R. et al.

application in histopathology of honey bee. Current Microscopy Contributions to Advances in Science and Technology, 2012, vol. 5, p. 696-703.

THIBAULT, C., SZÖLLÖSI, D. and GÉRARD, M. Mammalian oocyte maturation. Reproduction, Nutrition, Development, 1987, vol. 27 , n. 5, p. 865-896. http://dx.doi.org/10.1051/rnd:19870701. PMid:3317579.

ZELAZOWSKA, M., KILARSKI, W., BILINSKI, S.M., PODDER, D.D. and KLOC, M. Balbiani cytoplasm in oocytes of a primitive fish, the sturgeon Acipenser gueldenstaedtii, and its potential homology to the Balbiani body (mitochondrial cloud) of Xenopus laevis oocytes. Cell and Tissue Research, 2007, vol. 329, n. 1, p. 137-145. http://dx.doi.org/10.1007/s00441-007-0403-9. PMid:17364198.

ZUG, GR., VITT, LJ. and CALDWELL, JP. Herpetology: an introductory biology of amphibians and reptiles. 2nd ed. San Francisco: Academic Press, 2001. 630 p.
Received June 14, 2015 Accepted February 15, 2016 